\title{
PENGARUH WAKTU FERMENTASI TERHADAP VOLUME GAS BIO DAN PENYISIHAN COD DENGAN METODE PERLAKUANAWAL MENGGUNAKAN KALIUMHIDROKSIDA(KOH) PADA ECENG GONDOK (Eichhornia crassipes)
}

\author{
Setiaty Pandia, Amin Trisnawati* \\ Departemen Teknik Kimia, Fakultas Teknik, Universitas Sumatera Utara, \\ Jl. Almamater Kampus USU, Medan 20155, Indonesia \\ *Email : amintrisnawati@yahoo.co.id
}

\begin{abstract}
Abstrak
Penelitian ini bertujuan untuk mengetahui efek metode pre-treatment alkali terhadap kualitas dan kuantitas gas bio. Penelitian dilakukan pada eceng gondok dan $\mathrm{KOH}$ yang difermentasi pada konsentrasi 6,7 M; $4 \mathrm{M} ; 3 \mathrm{M}$; dan 2,9 M, dicampur dengan air pada rasio eceng gondok : air 70:30 $(\mathrm{v} / \mathrm{v}) ; 50: 50(\mathrm{v} / \mathrm{v}) ; 30: 70(\mathrm{v} / \mathrm{v})$ dan 100:0 (v/v) dan starter kotoran sapi didalam digester anaerobik sistem batch kapasitas 2,5 L. Pada penelitian ini produksi gas bio tertinggi terjadi pada konsentrasi KOH 4 M dengan rasio perbandingan eceng gondok : air 50:50 (v/v) dihasilkan volume gas bio 449 $\mathrm{mL}$. Pda penelitian ini persentase penyisihan COD sebesar $86,52 \%$ dan pernyisihan TSS sebesar $92,42 \%$. Sedangkan hasil minimum terjadi pada konsentrasi KOH 6,7 M dengan rasio perbandingan eceng gondok : air 70:30 (v/v) dihasilkan volume gas bio $132 \mathrm{~mL}$ dan persentase penyisihan COD sebesar $86,55 \%$ dan penyisihan TSS sebesar $88,65 \%$.
\end{abstract}

Kata kunci: eceng gondok, perlakuan awal, digester anaerobik, starter, $\mathrm{KOH}$

\begin{abstract}
The purpose of this study was to determine the effect of alkali pre-treatment methods on the quality and quantity of biogas. The study was doneby fermentation process the water hyacinth with $\mathrm{KOH}$ in a concentration of 6,7 M; $4 \mathrm{M} ; 3 \mathrm{M}$; and 2,95 (M) with water in ratio hyacinth: water 70:30; 50:50; 30:70 and 100:0 (v/v) mixed with cow dung starter in an anaerobic digester batch system of 2,5 L capacity. In this study the highest biogas production at $\mathrm{KOH}$ concentration $4 \mathrm{M}$ was in ratio of 50:50 (v/v)with yield biogas volume $449 \mathrm{~mL}$ and $86,52 \%$ of COD revomal, 92,42\% of TSS removal. The lowest biogas production at $\mathrm{KOH}$ concentration $6,7 \mathrm{M}$ was in ratio of 70:30 (v/v) with yield biogas volume $132 \mathrm{~mL}$ and $86,55 \%$ of COD removal and 88,65\% of TSS removal.
\end{abstract}

Keywords: hyacinth, pre-treatment, anaerobic digesters, starter, $\mathrm{KOH}$

\section{Pendahuluan}

Gas bio dapat dibuat dari eceng gondok, tetapi kendala yang dihadapi dalam pengolahan eceng gondok menjadi gas bio adalah keberadaan lignin dan hemiselulosa serta struktur dari selulosa yang sulit untuk diuraikan.Oleh karena itu perlu dilakukan pre-treatment untuk menguraikan lignin dan hemiselulosa dalam lignoselulosa [1]. Agar bakteri metagenik mampu tumbuh dan berkembang dengan baik dilakukan penambahan buffer untuk meningkatkan alkalinitas yaitu menggunakan $\mathrm{Na}_{2} \mathrm{CO}_{3}[12]$. Reaksi antara penyangga dengan asam adalah reaksi reversible (kesetimbangan) sehingga ketika terjadi kelebihan asam akan langsung dinetralkan oleh buffer (penyangga) [15]. Pre-treatment alkali dengan Kalium Hidroksida (KOH)bertujuan untuk memutuskan lignin pada eceng gondok dan mempercepat proses hidrolisis sehingga proses pembentukan gas metana lebih cepat, sedangkan penambahan natrium karbonat $\left(\mathrm{Na}_{2} \mathrm{CO}_{3}\right)$ bertujuan untuk mentralkan $\mathrm{pH}$ (5-7) pada slurry eceng gondok dengan proses anaerobik terhadap gas bio yang dihasilkan dan mempercepat proses pembentukan metana $\left(\mathrm{CH}_{4}\right)$ [4].Untuk mengoptimalkannya dilakukan semacam pretreatment yaitu dengan cara pengeringan dan memotong bahan baku lebih kecil [17].

Eceng gondok merupakan tanaman yang termasuk dalam family Pontederiaceae.Tanaman ini hidup di daerah tropis maupun subtropis. Eceng gondok digolongkan sebagai gulma perairan yang mampu menyesuaikan diri terhadap perubahan lingkungan dan berkembang biak secara cepat [20]. Pertumbuhan eceng gondok dapat mencapai $1,9 \%$ per hari dengan tinggi antara 0,3-0,5 m [21]. Perkembangbiakan dengan cara vegetatif dapatmelipat ganda dalam waktu 7-10 hari [4]. Eceng gondok ini biasanya tumbuh di kolam-kolam dangkal, tanah basah dan rawa, aliran air yang lambat, danau, tempat penampungan air dan sungai [7]. Di beberapa negara eceng gondok yang berhasil digunakan untuk produksi gas bio, Hasil penelitian mereka menunjukkan besar potensi eceng gondok sebagai sumber energi non - konvensional .Mereka memperkirakan bahwa 1 ton eceng gondok kering 
dapat menghasilkan 370.000 liter gas bio [19].Pada prinsipnya biomassa gulma berpotensi sebagai bahan untuk pembuatan bioenergi, seperti gas bio. [21].

\section{Teori}

Gas bio merupakan salah satu sumber energi terbarukan yang dapat menjawab kebutuhan dan energi alternatif yang ramah lingkunan dapat digunakan sebagai sumber energi penggerak generator listrik dan dibakar seperti gas elpiji (LPG) [20]. Gas bio ini dihasilkan dari anaerobik, dimana anaerobik adalah proses biologi dimana mikroba mendegradasi bahan organik tanpa adanya oksigen bebas dengan mencampurkan limbah hewan seperti kotoran sapi [9].Digesti anaerobik dapat dilakukan dengan satu tahap dan dua tahap. Pada proses satu tahap kempat proses yaitu, hidrolisis, asidognesis, asetognesis dan metanognesis dilakukan pada reaktor yang sama [10].

Hasil dari pembuatan gas bio dapat dijadikan sumber energi serta sisa keluaran berupa lumpur (sludge) dapat dijadikan pupuk siap pakai sehingga dapat menambah penghasilan [17]. Gas bio terdiri dari campuran metana $\mathrm{CH}_{4}$ sekitar 55-70\%, senyawa $\mathrm{CO}_{2}$ sekitar 25-50\%, kandungan $\mathrm{H}_{2} \mathrm{O}$ sekitar 1-5\%, kandungan $\mathrm{H}_{2} \mathrm{~S}$ sekitar $0-0,5 \%$, kandungan $\mathrm{N}_{2}$ sekitar $0-5 \%$ dan kandungan $\mathrm{NH}_{3}$ sekitar $0-0,05 \%$ [11].Pada tabel 1 dapat dilihat komposisi dari eceng gondok (berat kering) [23].

\section{Tabel 1. Komposisi Berat Kering Eceng Gondok}

\begin{tabular}{|c|c|}
\hline Senyawa Kimia & Persentasi (\%) \\
\hline Selulosa & 20 \\
\hline Hemiselulosa & 48,7 \\
\hline Lignin & 3,55 \\
\hline Silika & 5,56 \\
\hline Abu & 13,4 \\
\hline Total Solids $(\mathrm{TS})$ & $5,0-7,6$ \\
\hline Moisture & 95,5 \\
\hline
\end{tabular}

Teknologi pretreatmentyang dilakukan pada dasarnya adalah untukmengubah atau memindahkan komposisi dan struktur yang menghalangi proses hidrolisis yang bertujuan untuk meningkatkan laju aktivitasenzimatis dan hasil fermentasi yangmenghasilkan glukosa dari selulosa atau hemiselulosa [4].Bakteri pembentuk metan sangat peka terhadap tingkat keasaman atau sangat sensitif dengan $\mathrm{pH}$ yang rendah.Penurunan $\mathrm{pH}$ ini akan mengganggu kinerja bakteri pembentuk metan yang belum sempat berkembang. Adanya alkalinitas dalam reaktor dengan konsentrasi tertentu dapat menjadi penyangga (Buffer) agar $\mathrm{pH}$ tetap pada kondisi netral apabila terjadi penambahan asam, sehingga kesetimbangan proses secara keseluruhan dapat tetap berjalan dengan normal [16].

Lignin dalam hal ini dapat mempengaruhi waktu fermentasi dalam proses pembentukan gas bio oleh karena itu dilakukan proses treatment dengan Kalium Hidroksida $(\mathrm{KOH})$ dan Asam Sulfat $\left(\mathrm{H}_{2} \mathrm{SO}_{4}\right)$. Kalium Hidroksida dan Asam Sulfat membantu dalam proses hidrolisis dimana Kalium Hidroksida dan Asam Sulfat dapat membantu memecah lignin dan dinding sel serta melepaskan semua nutrisi dan bahan yang mudah dicerna dalam waktu yang singkat [15].

\section{Metodologi Penelitian}

\section{Alat dan Bahan}

Bahan yang digunakan pada penelitian ini adalah eceng gondok dan air, sebagai bahan pembantu digunakan glukosa dan mikroorganisme yang berasal dari kotoran sapi yang di campur dengan air dengan perbandingan 1: 1 yaitu $25 \%$ dari volume digester terisi (2 L). Alat utama yang digunakan ialah rangkaian alat digester anaerobik.

\section{Prosedur Percobaan}

Sampel (eceng gondok) dipotong $2 \mathrm{~cm}$ dan dikeringkan, ditreatment dengan $\mathrm{KOH}$ kemudian dinetralisasi dengan $\mathrm{H}_{2} \mathrm{SO}_{4}$ di campur air dalam rasio 70:30; 50:50; 30:70 dan 100:0 (w/w), kemudian ditambahkan starter (kotoran sapi) yang telah diaklimatisasi serta glukosa. Bahan isian dimasukkan ke dalam digester sebanyak $80 \%$ dari volume digester ( 2,5 L) yaitu sebanyak 2 L. Selanjutnya difermentasikan hingga tercapai keadaan tunak. Tangki digester dihubungkan ke alat pengukur volume biogas, dimana volume gas diukur setiap tiga hari.

Pada tahap ini percobaan dilakukan pada digester anaerobik sistem batch. Dengan $\mathrm{pH}$ dijaga konstan antara 6,2-8, dan pada temperatur lingkungan $\left(25-30{ }^{\circ} \mathrm{C}\right)$. Diamati paramaterparameter percobaan yaitu $\mathrm{pH}, \mathrm{COD}$ (Chemical Oxygen Demand), TSS (Total Suspended Solid), dan volume biogas hingga tercapai keadaan tunak, kemudian dilakukan uji nyala. Periode pengamatan dilakukan setiap 3 hari.

\section{Hasil Penelitian \\ Karakteristik Limbah Eceng Gondok}

Nilai COD dan TSS yang besar menunjukan tingginya kandungan zat organik di dalam limbah eceng gondok. Hal ini menunjukkan bahwa limbah ini bersifat mudah terbiodegradasi untuk 
dijadikan sebagai salah satu bahan baku pembuatan gas bio [5].Adapun karakteristik dari limbah eceng gondok sebelum fermentasi dapat dilihat pada tabel 2 .

Tabel 2. Karakteristik Limbah Eceng Gondok Sebelum Fermentasi

\begin{tabular}{|c|c|c|c|}
\hline Eceng gondok: Air & $\mathbf{p H}$ & $\begin{array}{c}\text { TSS } \\
(\mathbf{m g} / \mathbf{L})\end{array}$ & $\begin{array}{c}\text { COD } \\
(\mathbf{m g} / \mathbf{L})\end{array}$ \\
\hline $70: 30$ & 8 & 1850 & 15200 \\
\hline $50: 50$ & 7,5 & 1980 & 17800 \\
\hline $30: 70$ & 7 & 1600 & 14300 \\
\hline $100: 0$ & 8 & 2100 & 21970 \\
\hline
\end{tabular}

\section{Pembahasan \\ Pengaruh Waktu Fermentasi Terhadap Volume Gas Bio}

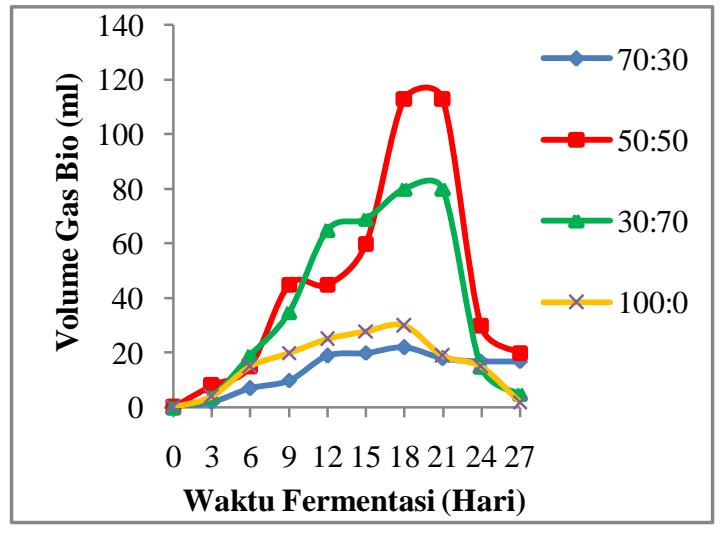

Gambar 2. Pengaruh Waktu Fermentasi Terhadap Volume Gas Bio

Dari gambar 2 di atas, dapat dilihat bahwa volume gas bio yang dihasilkan cenderung mengalami kenaikan kemudian menurun untuk setiap sampel. Pada penelitian ini perolehan gas bio paling maksimum dihasilkan pada konsentrasi KOH 4 M pada hari ke-18 menghasilkan gas bio $113 \mathrm{~mL}$. Sedangkan gas bio paling minimum diperoleh pada konsentrasi $\mathrm{KOH}$ 6,7 M pada hari ke -18 menghasilkan gas bio $22 \mathrm{~mL}$. Menurut Teori, semakin besar nilai COD pada suatu sampel maka gas bio yang dihasilkan semakin besar [5], namun pada grafik dapat dilihat COD tertinggi yaitu $21970 \mathrm{mg} / \mathrm{L}$ tidak menghasilkan gas bio tertinggi.

Berdasarkan penelitian yang pernah dilakukan dengan variabel berubah yang digunakan adalah konsentrasi $\mathrm{KOH}$ pada proses pre-treatment, yaitu 0, 0,5, 1, 3, dan $5 \mathrm{wt} \%$. Hasil penelitian menunjukkan bahwa konsentrasi $\mathrm{KOH}$ pada proses pre-treatment yang paling optimum adalah konsentrasi $3 \mathrm{wt} \%$, hal ini berarti bahwa bakteri memiliki titik jenuh pada konsentrasi
$\mathrm{KOH}$ tertentu yang mengakibatkan bakteri tidak dapat bekerja dengan baik $[10,15]$.

Pada gambar 2 dapat dilihat bahwa produksi gas bio maksimum pada hari ke-18 hal ini menunjukkan bahwa bakteri metanogenik bekerja secara maksimum pada hari ke-18, pada awal proses fermentasi bakteri pembentuk biogas (metanogen) mengalami masa penyesuaian dengan keadaan di dalam bahan baku, kemudian mengalami pertumbuhan karena adanya pemanfaatan nutrisi hingga dihasilkan produksi biogas maksimal [22]. Pada tahap akhir, fermentasi memasuki fase stasioner dimana bakteri mulai kekurangan nutrisi dan mengalami kematian sehingga produksi biogas cenderung konstan dan mulai menurun [2].

Efek metode pre-treatment pada eceng gondok adalah mempercepat proses hidrolisis pada proses fermentasi sehingga proses asidogenenesis, asetogenesenis dan metanogenesis dapat berlangsung lebih cepat, dalam penelitian kali ini proses pembentukan gas bio diamati dalam waktu 27 hari karena gas bio maksimum pada hari ke-18 dan menurun dalam waktu 27 hari tersebut. Dalam hal ini, pada konsentrasi $\mathrm{KOH} 4 \mathrm{M}$ menghasilkan gas bio maksimum yaitu $573 \mathrm{~mL}$ dalam waktu 27 hari. Berdasarkan penelitian terdahulu, tanpa proses pre-treatment dibutuhkan waktu 31 hari [15]. Oleh karena itu, pembuatan gas bio dengan proses pre-treatment memiliki potensi yang cukup bagus dibandingkang tanpa pre-treatment dari segi waktu yang singkat sehingga biaya yang dikeluarkan lebih sedikit.

\section{Pengaruh Waktu Fermentasi Terhadap Persentase PenyisihanChemical Oxygen Demand (COD)}

Dari gambar 3 dapat dilihat bahwa persentase penyisihan COD pada beberapa konsentrasi $\mathrm{KOH}$ cenderung semakin meningkat. Persentase penyisihan COD maksimum terjadi pada perbandingan eceng gondok : air 50:50 (v/v) dengan konsentrasi KOH 5,39 M pada hari ke- 27 persentase penyisihan COD sebesar 86,55\%. Untuk persentase penyisihan COD paling minimum terjadi pada perbandingan eceng gondok : air 70:30 (v/v) pada konsentrasi $\mathrm{KOH}$ 6,7 M hari ke-27 dengan persentase penyisihan COD sebesar $70,63 \%$.

Nilai COD yang besar menunjukan tingginya kandungan zat organik di dalam limbah eceng gondok. Hal ini menunjukkan bahwa limbah ini bersifat mudah terbiodegradasi untuk dijadikan sebagai salah satu bahan baku pembuatan gas bio [5]. Hasil penelitian menunjukkan pada beberapa komposisi sampel persentase penyisihan COD terus meningkat setelah hari ke-18 dimana produksi biogas maksimum.Dapat dikatakan pada saat produksi 
biogas optimum telah dicapai, bakteri tetap mampu mendegradasi senyawa organik meskipun volume biogas menurun.Oleh karena itu hasil penelitian yang diperoleh belum sesuai dengan teori yang ada.

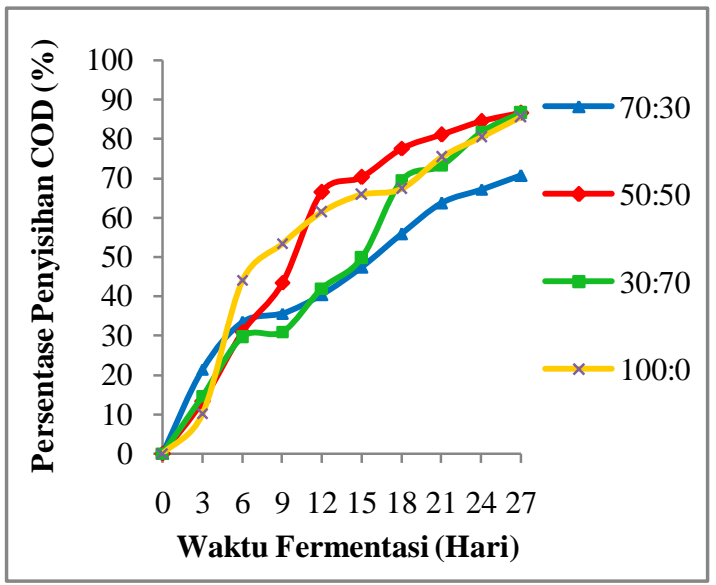

Gambar 3.Pengaruh Waktu Fermentasi Terhadap Persentase Penyisihan ChemicalOxygen Demand (COD) Pada Beberapa Sampel

Menurut PERMENLH No. 5/ 2014 tentang baku mutu air limbah bahwa limbah belum layak dilepaskan ke perairan lepas, apabila nilai CODnya lebih besar dari pada $200 \mathrm{mg} \mathrm{L}^{-1}$. Pada penelitian ini, nilai COD terendah dihasilkan pada konsentrasi $\mathrm{KOH} 4 \mathrm{M}$ dimana jumlah $\mathrm{COD}$ sebesar $2045 \mathrm{mg} \mathrm{L}^{-1}$ dengan persentase penyisihan COD sebesar $86,55 \%$ pada hari ke-27.

\section{Pengaruh Rasio Slurry dan Air Terhadap Persentase Penyisihan Total Suspended Solid (TSS)}

Dari gambar 4 dapat dilihat bahwa air yang digunakan akan mempengaruhi persentase penyisihan TSS. Pada penelitian ini persentase penyisihan paling maksimum diperoleh pada rasio eceng gondok : air 50:50 (v/v) konsentrasi $\mathrm{KOH}$ $4 \mathrm{M}$ (molaritas), persen penyisihan TSS terbesar terjadi pada hari ke-21 yaitu $83,79 \%$. Untuk persentase penyisihan paling minimum diperoleh pada perbandingan eceng gondok : air 100:0 (v/v) konsentrasi $\mathrm{KOH} 3 \mathrm{M}$ dimana persentase penyisihan TSS juga terjadi pada hari ke-21 yaitu sebesar 53,33\%.

Menurunnya nilai TSS diakibatkan karena bahan-bahan organik mengalami degadrasi pada saat proses pembentukan gas bio. Dimana molekul kompleks yang ada dipecah menjadi molekul yang lebih kecil [24].Namun setelah hari ke-21 pada beberapa komposisi nilai persentase penyisihan TSS cenderung stabil dan menurun disertai dengan menurunnya produksi gas bio. Hal ini menunjukan untuk beberapa komposisi pada saat fermentasi mencapai tahap akhir zat padat organik tidak mampu lagi didegadrasi secara maksimal oleh bakteri akibat jumlah nutrisi pada bahan baku yang semakin berkurang [50].

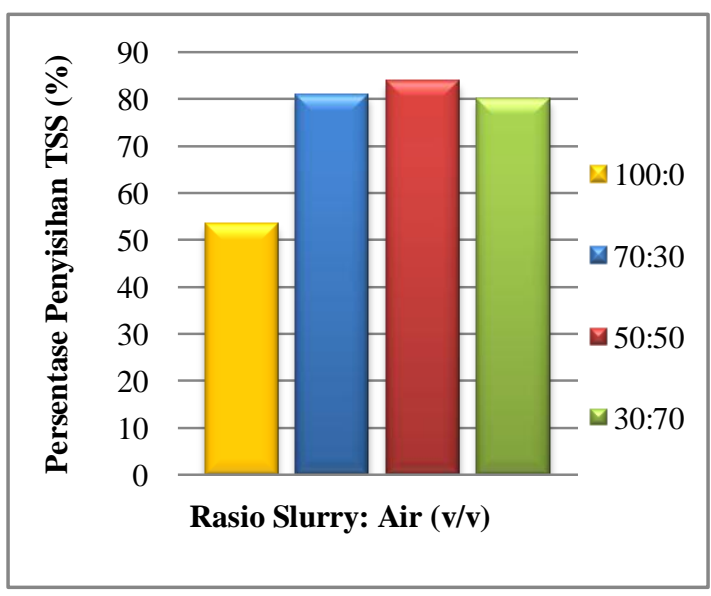

Gambar 4. Pengaruh Rasio Slurry dan Air Terhadap Persentase Penyisihan Total Suspended Solid (TSS) Pada Beberapa Sampel

Menurut PERMENLH No. 5/ 2014 tentang baku mutu air limbah bahwa limbah belum layak dilepaskan ke perairan lepas, apabila nilai TSS nya lebih besar dari pada $100 \mathrm{mg} \mathrm{L}^{-1}$. Pada penelitian ini, nilaiTSS akhir belum ada yang memenuhi standard pada semua sampel.

\section{Hasil Uji Nyala Gas Bio}

Hasil uji nyala gas bio pada penelitian ini dapat dilihat pada tabel 3 di bawah ini.

Tabel 3. Hasil Uji Nyala Gas Bio Pada Beberapa Perbandingan Sampel

\begin{tabular}{|c|c|}
\hline Eceng Gondok : Air & Hasil Uji Nyala \\
\hline $70: 30$ & Api berwarna biru \\
\hline $50: 50$ & Api berwarna biru \\
\hline $30: 70$ & Api berwarna biru \\
\hline $100: 0$ & Api berwarna biru \\
\hline
\end{tabular}

Metan $\left(\mathrm{CH}_{4}\right)$ adalah komponen penting dan utama dari gas bio karena memiliki kadar kalor yang cukup tinggi dan jika gas yang dihasilkan dari proses fermentasi anaerob ini dapat terbakar, berarti sedikitnya mengandung $45 \%$ metan. Berdasarkan penelitian yang telah dilakukan nyala api membuktikan berwarna biru. Apabila gas yang dihasilkan adalah $\mathrm{CO}_{2}$, api yang dinyalakan akan mati [2].

\section{Kesimpulan}

Volume gas bio maksimum diperoleh pada rasio eceng gondok : air 50:50 (v/v) dengankonsentrasi $\mathrm{KOH} 4 \mathrm{M}$ pada hari ke-18 dengan volume total gas bio sebesar 573 mL.Hasil analisa uji nyala gas bio pada setiap 
variasi menunjukan nyala api biru yang menandakan gas metan lebih dari 45\%.Proses pre-treatment kalium hidroksida dan asam sulfat pada bahan baku mengakibatkan waktu fermentasi lebih cepat (27 hari) daripada tanpa proses pre-treatment (31 hari).

\section{Daftar Pustaka}

[1] Abdillah, Jaka dan Gawa Reza Mahadin, Kalium Hidroksida $(\mathrm{KOH})$ Sebagai Hidrolisa Basa dalam Pre-Treatment Produksi Biogas dengan Bahan Baku Eceng Gondok,Skrispsi, Teknik Kimia, Institut Teknologi Semarang,2011.

[2] Agustina, Fransiska,Aplikasi Parameter Produk Biogas Dari Limbah Cair Industri Tapioka Dalam Bioreaktor Anaerobik 2 Tahap,Tesis Magister Teknik Kimia, UniversitasDiponegoro, Semarang,2011.

[3] Agustira, Riyanda,Kajian Beberapa Karakteristik Kimia Air, Fisika Air Dan Debit Sungai Pada Aliran Limbah Pabrik Tapioka Kawasan Das Padang Dan Sekitarnya, Skripsi,Program Studi Agroekoteknologi, Fakultas Pertanian. Universitas Sumatera Utara, Medan, 2012.

[4] Amriani, Feni, Praperlakuan Fisik dan Biologi Terhadap Biomassa Eceng Gondok untuk Produksi Enzim Selase oleh Aspergillus Niger dan Trichoderma Reesei. TesisTeknik Kimia, Fakultas Teknik, Universitas Sumatera Utara, Medan, 2013.

[5] Clinton, Deril,Pengaruh Waktu Fermentasi Dan Komposisi Limbah Kulit Buah Aren (Arenga Pinnata) Dengan Starter Kotoran Sapi Terhadap Biogas Yang DihasilkanSkripsi,Universitas Sumatera Utara,Medan, 2015.

[7] Dewi, Yusriani Sapta,Efektivitas Jumlah Rumpun Tanaman Eceng Gondok (Eichhornia Crassipes(Mart) Dalam Pengendalian Limbah Cair Domestik, Jurnal TeknikLingkungan,ISSN 1441-318X, Badan Pengkajian dan Penerapan Teknologi, Jakarta, 2012.

[8] Erdi Suroso, Model Proses Industri Tapioka Ramah Lingkungan Berbasis Produksi Bersih (Studi Kasus di Provinsi Lampung), Tesis, Sekolah Pascasarjana, Institut Pertanian Bogor, Bogor, 2011.

[9] Ehiri, R.C., I.I.Ikelle., , C. Mgbabor dan C.C. Ogbuanu, Kinetics of Biogas Production from a Mixture of Water Hyacinth (Eichornia Crassipes) and Fresh Rumen ISSN 0976-2612, Vol 2, Issue 1, pp 143147, 2011.

[20] Patil, Jagadish H, MAlourdu Antony Raj., P. L. Mularidhala, S. M. Desai dan G. K. Mahadeva Raju, Kinetics of Anaerobic
Residue, Journal of Applied Chemistry (IOSR-JAC) e-ISSN: 2278-5736, Volume 7, Issue 7 Ver. III, PP 36-39, 2014.

[10] Fikri, Adrianto Ahmad dan Sri Rezeki Muria, Pengaruh Perbandingan Eceng Gondok dengan Air Terhadap Penyisihan COD dan Padatan pada Produksi Biohidrogen secara Fermentasi Anaerob Batch Tahap Asidogenesis, Skripsi,Teknik Kimia, Fakultas Teknik, Universitas Riau, Pekanbaru, 2015.

[11] Haryati, Tuti, Biogas : Limbah Peternakan yang Menjadi Sumber Energi Alternatif, Balai Penelitian Ternak / PO Box 221, Bogor, 2006.

[12] Herawati, Dewi Astuti dan Andang Arif Wibawa, Pengaruh Pretreatment Jerami Padi pada Produksi Biogas dari Jerami Padi dan Sampah Sayur Sawi Hijau Secara Batch, Jurnal Rekayasa Proses, Vol. 4, No. 1, 2010.

[13] Khaerunnisa, Gita dan Ika Rahmawati, Pengaruh pH Dan Rasio COD:N Terhadap Produksi Biogas Dengan Bahan Baku Limbah Industri Alkohol (Vinasse), Jurnal Teknologi Kimia dan Industri, Vol.2, No.3, Hal : 1-7, 2013.

[14] Mulyani, Sasongko, dan Soetrisnanto. Pengaruh Preklorinasi Terhadap Proses Start Up Pengolahan Limbah Cair Tapioka Sistem Anaerobic Baffled Reactor, TesisMagister Teknik Kimia, Universitas Diponegoro, Semarang, Vol. 8, No. 1: 21- 27, April 2012.

[15] Ofoefule, A. U, E. O. Uzodinma dan O. D. Onukwuli, Comparative study of the effect of different pretreatment methods on biogas yield from water Hyacinth (Eichhorniacrassipes), International Journal of Physical Sciences Vol. 4 (8), pp. 535-539, 2009.

[16] Padang, Yesung Allo., Nurchayati dan Suhandi, Meningkatkan Kualitas Biogas Dengan Penambahan Gula Increasing Biogas Quality With Addition Sugar, Jurnal Teknik Rekayasa,Vol. 12 No. 1, 2011.

[17] Padmono, Djoko , Kemampuan Alkalinitas Kapasitas Penyangga (Buffer Capacity) Dalam Sistem Anaerobik Fixed Bed, Jurnal Teknik Lingkungan, 8 (2): 119-12, 2007.

[19] Patil, Jagadish H, MALourdu AntonyRaj dan C C Gavimath,Study On Effect of Pretreatment Methods On Biomethanation of Water Hyacinth, International Journal ofAdvanced Biotechnology and Research

Digestion of Water Hyacinth Using Poultry Litter as Inoculum, International Journal of Environmental Science and Development, Vol.2, No.2, 2012. 
[21] Sabour, M.F.Abdel, Water Hyacinth: Available And Renewable Resource, Electric Journal of Envitonmental, Agricultural and Food Chemistry,ISSN :1579-4377, Vol.9 (11).Hal : 1746-1759, 2010.

[22] Soemarno, Rancangan Teknologi Proses Pengolahan Tapioka dan ProdukProduknya,TesisMagister Teknik Kimia, Universitas Brawijaya, Malang, 2007.

[23] Singh, Lalit K, Gaurav Chaudhary, C. B, Majumder dan Sanjoy Ghosh, Utilization of hemicellulosic fraction of lignocellulosic biomaterial for bioethanol production, Advances in Applied Science Research, 2 (5):508-521, 2011.

[24] S. A Hauster,D. Dieter, Biogas from Waste and Renewable Resources. An Introduction(Singapore: WILEY-VCH Verlag GmbH \& Co. KGaA,Weinheim), 2008. 